\title{
The Influence Of ISO Certificate On Quality Evaluation of Students: A Case Study At Ishik University
}

\author{
Ahmet Demir \\ Ishik University, Sulaimani \\ Sinan Guven \\ Ishik University, Erbil
}

\begin{abstract}
In this study, the influence of ISO certificate on student satisfaction has been analyzed through investigating ISO standards which are implemented at Ishik University. Therefore, the impact of ISO certificate on education quality and its effects on student satisfaction have been studied. The data used in this study consists of information gathered through questionnaires and university database. The questionnaires were distributed to randomly chosen fifty students from each department. In this study three different scales were used: A questionnaire that includes 14 questions to assess courses and lecturers and a questionnaire that includes 10 questions to assess department heads. The collected data has been analyzed through Statistical Package for Social Sciences (SPSS). The influence of ISO certificate on student satisfaction is the major theme in the study. As a result, it has been found that when ISO implementation at Ishik University worked, the results have been shown on the findings and conclusion parts.
\end{abstract}

Keywords: ISO Certification, Quality Management System, Education Management, Total Quality Management

\section{INTRODUCTION}

ISO 9001:2008, which is a system to increase the quality level of companies, have provided very positive results at many education and business institutions. As a result of the implementation of ISO at companies, completed tasks (Naveh \& Marcus, 2004; Singh, 2008) and performance (Baird et. Al., 2011) will be positively affected. Furthermore, the implementation of ISO criteria will result loyalty among customers (Cianfrani et. Al., 2009; Corbett et. Al., 2005; Moreland \& Clark, 1998) and internal discipline of institutions (Cianfrani et. Al., 2009).

ISO quality management systems are implemented at various education institutions after the positive effects on various business companies. According to Van den Berghe (1997), implementation of ISO helps managers be more steady at their works, have a strong quality policy, and increase the loyalty to company. On another research, Thonhauser (2005) has found that those education institutions which implement ISO quality management systems act more regularly and with a discipline. On the other hand, Gozlu (1990) has claimed that although ISO quality management systems are implemented, the customer expectations must be evaluated otherwise it is impossible to mention about the customer satisfaction and loyalty.

Cetin et. Al., (2001) have determined on their researches that organizations must evaluate the expectations of the customers well. Kavrakoglu (1994) said that standards of ISO 9000 help organization increase the product quality. He claimed that as a consequence of quality product, the customer satisfaction also will be positively affected. 
Closely, Halis (2000) also defended that ISO 9000 will increase the quality of the outcomes and by this way customer satisfaction also will be positively affected. However, Akin (2001) and Tanyel (2001) claim that ISO 9000 is an important guide for the institutions which are willing to provide a quality service and production.

As of $21^{\text {st }}$ century, education Institutions must increase their quality for the satisfaction of the students. Quality is a very important weapon for the institutions in order to keep optimal performance at long run (Talip et. Al., 2010). Juran (1986) has defined the quality as conformance for use and divides quality into three; 1- Planning of Quality, 2- Quality Control, and 3- Improvement of Quality. Planning of quality is a process of an institution to achieve the goals and organizational objectives. In this process, the company should determine the expectations of the customers. Quality control is the process of achieving the goals and organizational objectives. Improvement of quality means exceeding the previous quality thresholds Juran (1986).

ISO quality certificate is a demand comes from the need of increasing the quality of a system at an institution. Quality is a name which is used to define the system, organizational structure, and resources...etc. Quality is a system that works in order to prevent the unwanted errors on the production or service (Moreland \& Clark, 1998).

ISO standards may help education institutions to increase quality and internal customers' satisfaction. The quality of education, effectiveness, and quality of services may increase by the help correct implementation of ISO quality management systems.

\section{Quality in Higher Education}

\section{LITERATURE REVIEW}

Quality became an important indicator to improve in education (Ehlers et. Al., 2005). Quality in education might be considered as ability of utilizing knowledge for the need of education. By that way, it is ability to conform the requirements and expectations of students from the education services points of view (Skrzypek, 2001). It is possible to provide a good education and contribution to the society and providing and improvement to them from the theoretical and practical points only by implementation of quality management systems. There are four main factors which decides about the quality of a university (Michalska-Cwiek, 2009); quality of potential material, quality of non-potential materials, quality of processes, and quality of outcomes.

Quality of potential materials might be defined as technical conditions of buildings and other utilities, capacities and amounts of educational rooms, qualities and amounts of educational materials, amounts and usability of tangibles, amounts of resources in the libraries, capacities and qualities of sports and other service utilities...etc. These utilities and availabilities in a university provides aesthetics, modernity, and neat neighborhood.

Quality of non-potential materials might mean the quality of academic and administrative staff, quality of education, titles that the academic staff having (professor, assist. prof, assoc. prof...etc.), experience of the staff, publications, inventions and patents, scientific researches...etc. These factors provide leadership, professionalism, individual culture and flexibility, and goal orientation...etc. Ittner ve Larker (1997) have determined that mission, vision, and strategy are very important parameters for institutions at these processes. 
Quality of processes might be defined as preparation of personnel, program, and schedule, variety of the works and quality of the lectures, determinants of evaluation of the lecturers, determining the administrative processes and announcing them properly. These aspects will provide responsibility to the work, loyalty, job satisfaction, kindness, equality, loyalty to the goals, and future oriented work environment.

Quality of the outcomes might be defined as percentage of graduates who can find job, number of foreign graduates, rank of university on the world sequence, awarded certificates and prizes, increasing number of publications and decrease at negative opinions about the institution and complaints. These aspects provide increase at positive perceptions of society, satisfaction of employee and employer, sensitiveness to reach and keep contact with the graduates.

\section{What is ISO?}

Standards of quality exist for along the centuries. For example, we can see some traces of quality standards at the period of Ottoman Emperor, Rome Emperor, China, India, and Japan on products and goods. In $15^{\text {th }}$ century, Ottoman Emperor has prepared standards, which included 100 articles, in Bursa, Edirne and Izmir. Those standards were stated to protect consumer. Those standards scope shops, groceries, producers, health service providers and other service institutes (Yucel and Burak, 2010; Gunduz, Kaya, and Aydemir, 2012). Loya and Boli (1999) have written that in most of the European countries quality standards were utilized. First modern standards are accepted as the standards of International Standards Association (ISA). After the Second World War, the importance of quality has increased and covered not only products and outcomes but also systems (Loya \& Boli, 1999).

After the Second World War, England has started using BS 5750 standards. Those standards became more important and International Standards Organization (ISO) was established in London (Loya \& Boli, 1999). ISO 9000:1987 standards were used firstly in England and between 1987 and 1994 those standards have been changed 250 times. Just after 1994, those standards have been used in 60 countries (Tricker \& Sherring_Lucas, 2001). Those standards have been revised and in 2000 under the name of ISO 9001:2000.

ISO 9000 standards are the standards which can be implemented any kind of institution in order to establish a strong quality management system (Kantner, 2000). ISO standards shapes a quality management system without deforming the current system of an institution.

The most important point here is nothing in this system plays secondarily role in processes. There are four main levels that an institution must conform in order to submit for ISO certificate. First of them is quality handbook. Secondly, the institution must prepare documentation system. Thirdly, Instructions must be prepared. Final level is support information documentation (Harding et. Al., 2000). Every institution doesn't apply to ISO with the same conditions of system. Each institution prepare their own system according to their needs (Singles, et. Al., 2001). Certification of a system means that this institution works systematically. However, ISO doesn't change procedures and standards based on country. They are the same for each institution, region, and country.

\section{Implementation of Quality Management System in Higher Education}

In higher education there are twelve steps of quality management systems (Karkoszka \& Szewieczek, 2007). First of all, top management must take decision for implementation of quality management system in university. Quality management systems commission should be 
established and start working coherently with the university management. Responsible staff for this system should be determined and their job descriptions must be defined. There must be a pre-evaluation of university system. The criteria of the quality management system should be defined and the lacking parts should be planned to be completed. To do this, top management should have training to learn about the theories and practices of quality management system. Documentation system of each process and procedures should be defined and prepared. Internal audits are selected among the current staff of the institution and then auditing operation should be performed. Finally external auditing operation should be performed and institution can be awarded ISO quality management certificate.

After this, the auditing operations are periodically must be repeated. Those twelve steps can be sequenced such as Michalska-Cwiek, J. (2009);

1. Decision about implementation of quality management system in university

2. Establishing quality management commission

3. Selecting staff for quality management system team

4. Pre-evaluation

5. Planning the system establishment process

6. Training the top management of university and establishing the structure of university

7. Determining the processes of university

8. Preparing the documentation of quality management system

9. Training internal audits

10. Implementation of the new system and auditing

11. Auditing for certification

12. Control auditing and activities for improvement

We can sequence the benefits of quality management systems to the universities such as (Ho, 1996; Dudek-Burlikowska, 2007);

1. Becoming sure about the data and source of information

2. Developing new techniques to improve university quality management system

3. Becoming sure about the flow of information among departments and units

4. Bringing innovative and effective solutions to the problems

5. Becoming sure about the functionality of departments and units of university

6. Decreasing the risk of making mistakes instead of correction of mistakes

7. Producing new techniques to improve the quality of education

8. Improvements on planning

9. Increasing the sense of responsibility

10. Increase on the motivation of the employees

11. Increase on the loyalty of the employees on their jobs. 


\section{Purpose of the Study}

\section{METHODOLOGY}

This study was conducted to study about satisfaction levels of students from the departments and lectures based on before and after ISO quality management systems certification. Secondly, study was conducted to understand the satisfaction of students on the units that they interact such as accounting, cafeteria, dean of students...etc.

\section{Model of the Study}

This study reaches findings based on the questionnaire results. Quantitative method was conducted to make this research. The questions have already been asked to the students for years. The results were evaluated based on before and after ISO for evaluation of lectures, lecturers, and department administrations.

\section{Population of the Study}

In this study, the population was collected among the students who are studying in Erbil city which is located on the Northern Part of Iraq. Approximately 20 students from each department was chosen. On the other hand, the population might show increase on 2015 regarding to 2013 due to the increase on number of departments from 2013 until 2015.

Table 1 Distribution of students who have participated in the study

\begin{tabular}{|l|l|}
\hline 2013 Year Departments & 2015 Year Departments \\
\hline Dentistry & Dentistry \\
\hline Civil Engineering & Civil Engineering \\
\hline Computer Engineering & Computer Engineering \\
\hline Computer Sciences & Computer Sciences \\
\hline Business and Management & Business and Management \\
\hline English Language Teaching & English Language Teaching \\
\hline Math Teaching & Math Teaching \\
\hline Accounting & Accounting \\
\hline Law & Law \\
\hline & Architectural Engineering \\
\hline & Internal Design \\
\hline & Physics Teaching \\
\hline & Biology Teaching \\
\hline & Law \\
\hline
\end{tabular}

\section{Measuring Scales}

The data which was used in this study was collected from the database of the University and result of survey conducted to the students during the research.

In this concept, 3 survey was utilized as; 
Survey of ministry of higher education which consist of 14 questions to measure the quality of lecture and lecturer

Survey of ministry of higher education which consist of 10 questions to measure the quality of administration of department

\section{Lecture and Lecturer Evaluation}

\section{FINDINGS}

The survey, which data was observed from, is existing on student information system data base. The information before and after ISO certification was investigated and analyzed. The results are shown on table below.

Table 2 group Statistics of Lecture and Lecturer Evaluation

\begin{tabular}{|l|c|c|c|c|}
\hline & ISO & Mean & Std. Dev. & Std. Mean Error \\
\hline Lecturer and & Before ISO & 3.6854 & .26255 & .03790 \\
\cline { 2 - 5 } & & & & .05996 \\
\cline { 2 - 5 } Eecture & After ISO & 3.8667 & .25437 & \\
\hline
\end{tabular}

It was seen from the table 2 that lecture and lecturer evaluation results was 3.69 before ISO quality management system was conducted. This number increases up to 3.87 after ISO was conducted (After one Year). In order to understand if this increase was significant or coincidental, table 2 need to be studied.

Table 3 Results of Independent Samples t-test

\begin{tabular}{|c|c|c|c|c|c|c|c|c|c|c|c|}
\hline \multicolumn{3}{|c|}{$\begin{array}{c}\text { Independent } \\
\text { Samples T-Test }\end{array}$} & \multicolumn{3}{|c|}{$\begin{array}{c}\text { Levene's Test } \\
\text { Result }\end{array}$} & \multicolumn{6}{|c|}{$\begin{array}{c}\text { Mean Difference of } \\
\text { t-test }\end{array}$} \\
\hline & & & \multirow[t]{2}{*}{$\mathrm{F}$} & \multirow[t]{2}{*}{$\begin{array}{c}\text { Sig } \\
\text {. }\end{array}$} & \multirow[t]{2}{*}{$\mathrm{T}$} & \multirow[t]{2}{*}{$\mathrm{df}$} & \multirow[t]{2}{*}{$\begin{array}{l}\text { Sig. (2- } \\
\text { tailed) }\end{array}$} & \multicolumn{2}{|c|}{$\begin{array}{c}\text { Mean } \\
\text { Difference }\end{array}$} & \multicolumn{2}{|c|}{$\begin{array}{c}\text { 95\% Confidence } \\
\text { Interval }\end{array}$} \\
\hline & & & & & & & & & & Min & Max \\
\hline \multirow{7}{*}{ 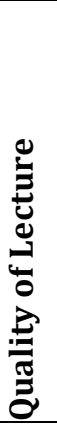 } & \multirow{7}{*}{ 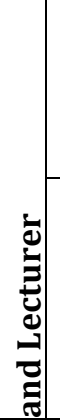 } & Equal & .06 & .79 & -2.518 & 64 & .014 & - & .07197 & -.32503 & -.03747 \\
\hline & & Variance & 7 & 7 & & & & .1812 & & & \\
\hline & & Assumed & & & & & & 5 & & & \\
\hline & & Equal & & & -2.555 & 31.479 & .016 & - & .07093 & -.32582 & -.03668 \\
\hline & & Variance & & & & & & .1812 & & & \\
\hline & & Not & & & & & & 5 & & & \\
\hline & & Assumed & & & & & & & & & \\
\hline & & 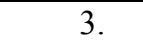 & & & & & & & & & \\
\hline
\end{tabular}

Table 3 shows whether the difference of before and after ISO is significant or not. In order to accept this difference as significant, $t$ result on the table must be above +1.96 or below -1.96 . another indicator can be alpha level of the analysis must be below 0.05 level and only in this case the difference can be accepted as to be significant and otherwise it is coincidental. According to table 3, the $t$ value seems to be above 2.50 and this shows that the difference 
occurred after implementation of ISO quality management system is significant. In another saying, it shows that Ishik University has improved the quality after implementation of ISO quality management system. Furthermore, Regression analysis proposed to see the impact as percentage that ISO certification made.

Table:4 Results of Regression Analysis

\begin{tabular}{|c|c|c|c|c|c|}
\hline \multirow[t]{2}{*}{ Model } & \multicolumn{2}{|c|}{$\begin{array}{c}\text { Unstandardized } \\
\text { Coefficients }\end{array}$} & \multirow{2}{*}{$\begin{array}{c}\begin{array}{c}\text { Standardized } \\
\text { Coefficients }\end{array} \\
\text { Beta }\end{array}$} & \multirow[t]{2}{*}{$\mathbf{t}$} & \multirow[t]{2}{*}{ Sig. } \\
\hline & $\mathrm{B}$ & Std. Error & & & \\
\hline (Constant) & 3.504 & .097 & & 36.108 & .000 \\
\hline ISO & .181 & .072 & .300 & 2.518 & .014 \\
\hline \multicolumn{6}{|c|}{ a. Dependent Variable: Lecture and Lecturer Evaluation } \\
\hline
\end{tabular}

It can be seen on table 4 that ISO had a significant impact on lecture and lecturer evaluation of students. Furthermore, adjusted R square was 0.09 and this means that implementation of ISO quality management system has affected students evaluation $9 \%$. As of only one year that ISO quality management system has been implemented in the University, this amount of change can be considered as good.

\section{Evaluation of Departments Administration}

In this section, quality of department administration was evaluated from the students' perspective. This information also was obtained from the database of the University. Independent samples t test was conducted on the data and analysis results were shown on table 5.

Table 5 Group Statistics

\begin{tabular}{|c|c|c|c|c|}
\hline & ISO & Mean & Std. Devi & Std. Error Mean \\
\hline \multirow{2}{*}{$\begin{array}{l}\text { Quality of } \\
\text { Department } \\
\text { Administrations }\end{array}$} & $\begin{array}{l}\text { Before ISO } \\
\text { Certificate }\end{array}$ & 4.4208 & .39047 & .07970 \\
\hline & $\begin{array}{l}\text { After ISO } \\
\text { Certificate }\end{array}$ & 4.6913 & .29245 & .07551 \\
\hline
\end{tabular}

It is blatant on table 5 that there is a difference between evaluation results of department administrations based on before and after ISO certification. It became 4.69 while the result of evaluation was 4.42 before ISO implementation. So that it can be said that a difference occurred after implementation of quality management system. In order to check if this difference was significant or coincidental, independent samples t test results were shown on table 6. 
Table:6 Results of Independent Samples t test

\begin{tabular}{|c|c|c|c|c|c|c|c|c|c|}
\hline \multirow[t]{2}{*}{$\begin{array}{l}\text { Independen } \\
t \quad \text { Sample }\end{array}$} & \multicolumn{2}{|c|}{$\begin{array}{l}\text { Levene's Test } \\
\text { for Equality }\end{array}$} & \multicolumn{7}{|c|}{ t-test for Equality of Means } \\
\hline & & & & & & Mean & $\begin{array}{l}\text { Std. } \\
\text { Error }\end{array}$ & \multicolumn{2}{|c|}{$\begin{array}{l}95 \% \text { Confidence } \\
\text { Interval of the } \\
\text { Difference }\end{array}$} \\
\hline & $\mathrm{F}$ & Sig. & $\mathrm{t}$ & $\mathrm{df}$ & Sig. (2- & Differenc & Differenc & Lowe & Upper \\
\hline $\begin{array}{l}\text { Equal } \\
\text { varian } \\
\text { ces } \\
\text { assum } \\
\text { ed }\end{array}$ & $\begin{array}{l}1.68 \\
1\end{array}$ & .203 & $\begin{array}{l}- \\
2.305\end{array}$ & 37 & .027 & -.27050 & .11736 & $\begin{array}{l}- \\
.5082\end{array}$ & -.0327 \\
\hline $\begin{array}{l}\text { Equal } \\
\text { varian } \\
\text { ces not } \\
\text { assum }\end{array}$ & & & $\begin{array}{l}- \\
2.464\end{array}$ & $\begin{array}{l}35.6 \\
4\end{array}$ & .019 & -.27050 & .10979 & -4932 & -.0477 \\
\hline
\end{tabular}

It was seen that $\mathrm{t}$ value was below -1.96 and this shows that the result is not coincidental. So this difference is considered to be significant. As a result, only after one year of implementation of ISO quality management system, students' perception was positively affected. In order to see the percentage of this difference, regression analysis performed and results were shown on table 7.

Table 7 Results of Regression Analysis

\begin{tabular}{|c|c|c|c|c|c|c|}
\hline \multicolumn{2}{|r|}{ Model } & \multicolumn{2}{|c|}{$\begin{array}{c}\text { Unstandardized } \\
\text { Coefficients }\end{array}$} & \multirow{2}{*}{$\begin{array}{c}\text { Standardized } \\
\text { Coefficients }\end{array}$} & \multirow[t]{2}{*}{$\mathbf{t}$} & \multirow[t]{2}{*}{ Sig. } \\
\hline & & B & Std. Error & & & \\
\hline \multirow[t]{2}{*}{1} & (Constant) & 4.150 & .172 & & 24.097 & .000 \\
\hline & ISO & .270 & .117 & .354 & 2.305 & .027 \\
\hline
\end{tabular}

It was seen that adjusted R square was 0.10 and it can be said that ISO certification affected the evaluation of students $10 \%$. Furthermore, this explained variance and effect of implementation of ISO quality management system was significant. It can be said that it was only the first year of implementation of this system and the results were affected positively.

\section{CONCLUSIONS}

This study was proposed in order to see if ISO certification and implementation has an influence on the quality of education in the universities. Evaluation of lecture and lecturer was 3.69 on average before ISO implementation and it became 3.86 after the implementation of this quality management system. According to the results that we have obtained from this study shown us that ISO quality management system had impact on evaluation of lecture and 
lecturers positively. Due to it was the first year of implementation, the results can be considered as good.

The evaluation results of departments administration has shown us that before the implementation of ISO the evaluation on average was 4.42 and it became 4.69 after ISO was implemented in the University. So this result shows that within one year perception about the department administration has been affected positively.

As a result, it can be said that implementation of ISO quality management system has affected the perception of students positively on quality of lectures, lecturers, and department administration. On lectures and lecturers the effect was $9 \%$ and on department administration $10 \%$. So that in both cases it can be said that ISO had approximately $10 \%$ of impact on the quality of education after one year.

This study was performed only in Ishik University, Erbil. This can be considered as limitation of this study. There are many different universities which has been implementing ISO quality management system for years all around the world. From this point of view, for the further studies this method can be implemented to different universities and the results can be compared. Moreover, the study can be conducted during several years and the results can be compared.

\section{References}

Akin, Ö. (2001). Toplam Kalite Yönetimi ve insan. Bursa: Ezgi Kitabevi.

Baird, K., Hu, K. J., \& Reeve, R. (2011). The relationships between organizational culture, total quality management practices and operational performance. International Journal of Operations \& Production Management, 31(7), 789814.

Cetin, C., Besim, A., \& Erol, V. (2001). Toplam Kalite Yonetimi ve Kalite Guvence Sistemi. Istanbul: Beta Yayinlari Cianfrani, C. A., Tsiakals, J. J., \& West, J. (2009). ISO 9001: 2008 explained: Asq Pr.

Dudek-Burlikowska, M. (2007). Quality estimation of sale process with usage of quality methods in chosen company. Journal of Achievements in Materials and Manufacturing Engineering, 20, 531-534.

Ehlers, U.-D., Hildebrandt, B., Görtz, L., \& Pawlowski, J.M. (2005). Use and distribution of quality approaches in European e-learning. Thessaloniki, Greece: CEDEFOP.

Gozlu, S. (1990). Endustriyel Kalite Kontrolu. Istanbul: Istanbul Teknik Universitesi.

GUNDUZ, A. Y., KAYA, M., \& AYDEMİR, C. (2012). AHİLİK TEŞKILLATINDA VE GÜNÜMÜZDE TÜKETİCILLERİN KORUNMASINA YÖNELİK ÇALIŞMALAR ÜZERİNE BİR DEĞERLENDİRME. Journal of Economics \& Administrative Sciences/Afyon Kocatepe Üniversitesi Iktisadi ve Idari Bilimler Fakültesi Dergisi, 14(2).

Halis, M. (2000). Toplam Kalite Yönetimi.Istanbul: Beta Yayinevi.

Harding, K.A., Tesolowski, D.G., \& Simmons, J.B. (2000). Enhancing technology education students understanding of ISO 9000 [Electronic version]. Tech Directions, 59 (9), 32-36.

Ho, S.K. (1996). An integrated approaching-implementing total quality through Japenese $5 S$ and ISO 9000. Kogan Page, London: England.

Ittner, C. D. \& Larcker, D. F. (1997). Quality strategy, strategic control systems, and organizational performance. Accounting, Organizations and Society, 22 (3-4), 293-314.

Juran, J. M. (1986). Universal Approach to Managing for Quallity: The Quality Trilogy.

Kavrakoglu, I. (1994). Toplam Kalite Yönetimi. Istanbul: Kalder Yayinlari.

Karkoszka, T., and D. Szewieczek. "Risk of the processes in the aspect of quality, natural environment and occupational safety." Journal of Achievements in Materials and Manufacturing Engineering 20.1-2 (2007): 539542. 
Loya, T.A., \& Boli, J. (1999). Standardization in the world polity: Technical rationality over power. In J.Boli \& G.MThomas (Eds.), Constructing world culture: International nongovernmental organizations since 1875 (pp. 169-197). Stanford, CA: Stanford University Press.

Michalska-Cwiek, J. (2009). The quality management system in education - implementation and certification. Journal of Achievements in Materials and Manufacturing Engineering, 37(2), 743-750.

Moreland, N., \& Clark, M. (1998). Quality and ISO in educational organizations. Total Quality Management, 9(2-3), 311-320.

Naveh, E., \& Marcus, A. A. (2004). When does the ISO 9000 quality assurance standard lead to performance improvement? Assimilation and going beyond. Engineering Management, IEEE Transactions on, 51(3), 352-363.

Singh, P. J. (2008). Empirical assessment of ISO 9000 related management practices and performance relationships. International Journal of Production Economics, 113(1), 40-59.

Skrzypek, E. (2001). The quality of the education process at the university. Quality Problems, 10, 13-22.

Talib, F., Rahman, Z., \& Qureshi, M. (2010). The relationship between total quality management and quality performance in the service industry: a theoretical model. International Journal of Business Management and Social Sciences, 1(1), 113-128.

Tanyel, F. (2001). Kucuk ve Orta Olcekli Isletmelerimizde ISO-9000 Uygulamalari. Ankara: KOSGEB.

Thonhauser, T. L. (2005). Factors that relate to the successful implementation of ISO 9000 in education: A comparison between the United States and England. THE PENNSYLVANIA STATE UNIVERSITY.

Tricker R., \& Sherring-Lucas, B. (2001). ISO 9000: 2000 in brief. Boston: Butterworth-Heinemann.

Van den Berghe, W. (1998). Application of ISO 9000 standards to education and training. European Journal, 15, 2028. 